\title{
ТЕМА «РОЗВИТОК УКРАЇНСЬКОЇ МОВИ»: ПОСИЛЕННЯ ІНФОРМАЦЙНОЇ СКЛАДОВОЇ (ДО УРОКУ В 9 КЛАСІ)
}

Малюга Н. М. Тема «Розвиток української мови»: посилення інформаційної складової (до уроку в 9 класі).

Статтю присвячено проблемі застосування результатів мовознавчих досліджень у практиці проведення вступних уроків з української мови. Запропоновані матеріали покликані виробити вміння розумітися на складних питаннях функціонування мови в суспільстві. Автор скеровує роботу суб'єктів навчального процесу на поглиблене опрацювання спеціальної літератури, на вивчення дискусійних питань, що має вагоме значення в успішній соціалізації учнів і випускників навчальних закладів.

Ключові слова: українська мова, теорії походження, нищення української мови і культури, уроки загальнолінгвістичної тематики. 
Малюга Н. Н. Тема «Развитие украинского языка»: усиление информационной составляющей (к уроку в 9 классе).

Статья посвящена проблеме применения лингвистических исследований в практике проведения вступительных уроков по украинскому языку. Предложенные материалы помогуг выработать умение ориентироваться в сложных вопросах функционирования языка в обществе. Автор переориентировует работу субъектов учебного процесса на углубленное изучение специальной литературы, дискуссионных вопросов, что имеет большое значение в успешной социализации учащихся и выпускников учебных заведений.

Kлючевые слова: украинский язык, теории происхождения, уничтожение украинского языка и культуры, уроки общелингвистической тематики.

Maliuga N. M. Subject "The development of Ukrainian language": reinforcement of informational component (to lesson in 9 form).

The article examines the problem of using linguistic studies in implementation of introductory Ukrainian lessons. Proposed materials help to elaborate skills to know difficult questions of language functioning in society. The author reorients students' work on extended studying of special literature, discussion questions that have great importance in successful students' and school-leavers' socialization.

Key words: Ukrainian language, origin theories, destruction of Ukrainian language and culture, general linguistic lessons.

Коли вчителі рідної мови висловлюють незадоволення «низькою научуваністю» своїх учнів щодо письмового та усного слововжитку, вони викривають убозтво в начитаності школярів під натиском сучасної поширеної в усьому світі молодіжної культури, яка живиться i поширюється насамперед Інтернетом, телебаченням, аудіо- й відеозаписами, особистиими взаєминами.

Звичка користуватися російською в побуті при вимушеному переході на українську в навчальному процесі чи професійній діяльності породжує явище так званої «дерев'яної мови»; мовцям бракує природності вимови, достатнього лексичного запасу, виразності, гнучкості під час добору засобів. Пародійні рядки Олександра Ірванця «Як ти звучиш калиново-дубово, рідна моя українськая мова» асоціюються саме 3 таким поширеним типом мовлення, пов'язаним 3 натужним внутрішнім перекладом із російської.

Нам доводиться зустрічати чимало молодих людей, які мислять примітивно, хоч їхні голови заповнені «уривками» сучасних наук. Про сучасний стан та історію культури людства школа дає лише не пов'язані між собою уривки знань, які претендують на нереальну позачасовість одночасно з утратою історичної перспективи й розуміння тенденцій розвитку, тому результатом освіти, замість бажаного і реального знання, $\epsilon$ повна дезорієнтація. Тільки матеріал рідної мови, яким володіє кожен 
учень, виявляє найрізноманітніші зв'язки, може весь час розширюватися, створюючи тим самим безпосередній місток 3 оточенням дитини, перетворюючи іï на члена великої спільноти. Це відбувається на основі реальних фактів, які укладаються в одну систему.

До висвітлення важливих мовознавчих питань шкільного курсу української мови звертаємося не вперше. Свого часу ми обгрунтовували необхідність застосування результатів мовознавчих досліджень у курсі української мови в середній школі, окреслювали шляхи подолання хибної практики проведення вступних уроків загальнолінгвістичної тематики $[1 ; 2 ; 3]$. Свою мету вбачаємо в тому, щоб через ознайомлення вчителя-словесника 3 результатами етно-, соціолінгвістичних та власне мовознавчих досліджень посилити інформаційну складову вступних уроків 3 української мови, що сприятиме підвищенню пізнавальної активності учнів.

У 9 класі мовною змістовою лінією Програми для загальноосвітніх навчальних закладів з української мови 5-12 класи передбачено тему «Розвиток української мови». Згідно 3 державними вимогами до рівня загальноосвітньої підготовки учень повинен знати, як здійснювався процес i результат розвитку української мови в ході історичного становлення українського суспільства та його культури [4, с. 111].

В аспекті реалізації соціокультурної змістової лінії задля дослідження сфери відношень «Я і українська мова та література» рекомендовано опрацювати тексти 3 теми «Розвиток української мови»; для побудови власних висловлювань учнів запропоновано тему «Спіши у храм святого слова».

Щодо походження української мови як унікального цілісного лінгвістичного явища тривалий час співіснують схожі, близькі та полярні концепції, різноманітні періодизації, які віддаляють або наближують витоки української мови до того чи того історичного періоду.

Над проблемою походження української мови вчені почали замислюватися задовго до здобуття Україною незалежності, ще в ХІХ ст., саме тоді спалахнуло кілька дискусій між російськими й українськими науковцями щодо виникнення української мови. Коли українці були ізольовані від власних національних надбань, єдино правильною вважалася позиція, за якою початок формування української мови, як і російської та білоруської, припадає на XIII-XIV ст., період падіння середньовічної держави Київська Русь. «Материнською колискою» 
української, російської та білоруської мов проголошувалася давньоруська, або спільносхіднослов'янська мова (період ії розвитку - VIII-XIII ст.).

У дусі радянської науки свого часу періодизував історію української мови Ф. Медведєв за такими етапами: 1) давньоруська мова - приблизно від початку VII - до XIV ст.; 2) мова російської, української, білоруської народностей від XIV до XVII ст.; 3) російська, українська і білоруська національні мови від XVIII ст. до нашого часу.

О. Горбач запропонував власну періодизацію із такими етапами: А. Етапи виникнення української мови серед інших слов'янських: 1) праіндоєвропейська доба (2000 р. до н. е.?); 2) балто-слов'янська доба (1500-1300 рр. до н. е.?); 3) праслов'янська доба (1300 р. до н. е. 500/800 pр. н. е.); 4) протосхіднослов'янська доба (500/800-900/1000 pр. н. е.). Б. Виникнення української мови в іï двох діалектах - південнозахідному і північно-східному - з їхніми системами (XI/XII-XV ст.).

За розвитком основних фонологічних змін Ю. Карпенко періодизує історію української мови: 1) праслов'янська мова (кінець II тис. до н. е.); 2) спільна мова східних і південних слов'ян (II ст. до н. е. - IV ст. н. е.); 3) спільносхіднослов'янська мова (IV-X ст.) - антська мова (IV-VII ст.), давньоруська (VIII-X ст.); 4) давньоукраїнська мова (XI-XIV ст.); 5) староукраїнська мова (XV-XVIII ст.); 6) нова українська мова (XIX-XX ст.).

В. Німчук пропонує таку періодизацію історії української мови: 1) праслов'янська мова 3 протосхіднослов'янськими діалектами в іiі складі; 2) давньоруськоукраїнська мова (XI-XIII ст.); 3) середньоукраїнська мова, або середньоукраїноруська мова (XIV/XV кінець XVII ст.): а) рання середньоукраїнська мова (XIV/XV - перша половина XVI ст.); б) пізня середньоукраїнська мова (друга половина XVI - кінець XVII ст.); 4) новоукраїнська мова (від кінця XVII ст.).

Ю. Шевельов історію української мови поділив на чотири періоди: 1) протоукраїнська мова (VII-XI ст.); 2) староукраїнська мова (XI-XIV ст.); 3) середньоукраїнська мова: а) рання середньоукраїнська мова (кінець XIV - кінець XVI ст.); б) середньоукраїнська мова (кінець XVI - початок XVIII ст.); в) пізня середньоукраїнська мова (початок XVIII - початок XIX ст.); 4) нова українська мова (XIX ст. - наш час).

Не витримала критики псевдонаукова теорія походження української мови російських мовознавців XIX ст. М. Погодіна i О. Соболевського, які стверджували, що: 1) у стародавньому Києві та на Київщині включно до кінця XIV ст. жили росіяни; 2) київський говір 
належить не до української мови, а до російської; 3) українська мова розвинулася від російської мови, почала самостійне існування з XV ст.

1866 року Паризьке лінгвістичне товариство внесло до свого статуту пункт, який, зокрема, оголошує, що Товариство не приймає до розгляду праці про походження мови. 1873 року це рішення підтримало Лондонське філологічне товариство. Отже, самі мовознавці визнають, що питанням походження мови лінгвістика займатися не повинна.

Розкриття питання про розвиток української мови передбачає висвітлення фактів, що засвідчують гальмівні процеси функціонування української мови на споконвічних теренах проживання іiі носіїв та перешкоджання розвою культури народу. Документи про заборону української мови в царській Росії добре відомі, ми ж сконцентруємо свою увагу на заходах із нищення української мови і культури після Жовтневої революції і до кінця ХХ ст.

\begin{tabular}{|c|c|}
\hline Рік & Фіксація події \\
\hline 1918 & $\begin{array}{l}\text { Захопивши Київ (26 січня), більшовицькі інтервенти за кілька днів } \\
\text { розстріляли } 5 \text { тис. осіб, які розмовляли українською мовою, носили } \\
\text { український національний одяг або в кого в оселі висів портрет Т. Шевченка. }\end{array}$ \\
\hline $1921-1930$ & $\begin{array}{l}\text { Промосковські шовіністичні сили в Україні чинять шалений опір } \\
\text { відродженню української мови й українських культурних традицій, яке } \\
\text { пустило глибоке коріння в роки Української національної революції. «Зачем } \\
\text { возрождать допетровскую эпоху, зачем гальванизировать украинский язык, } \\
\text { который покрылся уже прахом», - повчав у Запоріжжі російський } \\
\text { письменник Ф. Гладков. «Признання української мови як урядової могло б } \\
\text { означати панування української буржуазії та куркульства», - писав голова } \\
\text { «українського» уряду Х. Раковський. }\end{array}$ \\
\hline 1922 & $\begin{array}{l}\text { Проголошення частиною керівництва ЦК РКП(б) і ЦК КП(б)У «теорії» } \\
\text { боротьби в Україні двох культур - міської (російської) та селянської } \\
\text { (української), у якій повинна перемогти перша. }\end{array}$ \\
\hline $1922-1934$ & $\begin{array}{l}\text { Хвиля насильства проти неповторного і яскравого явища української та } \\
\text { світової культури - кобзарства. Українські національні музичні } \\
\text { інструменти - кобзу, бандуру та ліру - оголошують націоналістичними і } \\
\text { знищують. Натомість в Україну завозять десятки тисяч балалайок } \\
\text { гармошок. Кобзарів оголошують жебраками і жорстоко переслідують. Щоб } \\
\text { спотворити пам’ять і роль кобзарства, комуністи створюють капели } \\
\text { бандуристів, які виконують пісні на замовлення та під контролем НКВС, а } \\
\text { керівництво ними передається в руки чужинців. }\end{array}$ \\
\hline 1924 & $\begin{array}{l}\text { Закон Польської республіки про обмеження вживання української мови в } \\
\text { адміністративних органах, суді, освіті на підвладних полякам } \\
\text { західноукраїнських землях. Закон Румунського королівства про } \\
\text { зобов’язання всіх румунів, які «загубили матірну мову», давати дітям } \\
\text { освіту лише в румунських школах. }\end{array}$ \\
\hline
\end{tabular}

() Н. М. Малюга, 2014. 


\begin{tabular}{|c|c|}
\hline 1925 & Остаточне закриття українського «таємного» університету у Львові. \\
\hline 1926 & $\begin{array}{l}\text { Лист Сталіна «Тов. Кагановичу та іншим членам ПБ ЦК КП(б)У» } \\
\text { санкцією на боротьбу проти «національного ухилу», початок } \\
\text { переслідування діячів «українізації». }\end{array}$ \\
\hline 1929 & $\begin{array}{l}\text { Арешт українських науковців та духовенства }- \text { заміщення їх } \\
\text { російськомовними. }\end{array}$ \\
\hline $1929-1930$ & $\begin{array}{l}\text { Арешти визначних діячів української науки, культури, освіти, Церкви, } \\
\text { харківський судовий процес над ними (процес «Спілки Визволення } \\
\text { України»). На допиті одного } 3 \text { арештованих, В. Дурдуківського, слідчий } \\
\text { Соломон Брук сказав: «Нам надо украинскую интеллигенцию поставить на } \\
\text { колени, это наша задача. Кого не поставим - перестреляем». У ці роки на } \\
\text { території УСРР заарештовано (і здебільшого розстріляно або відправлено на } \\
\text { довгострокову каторгу в концтабори) понад } 120 \text { тис. українців, головним } \\
\text { чином інтелігенції. До звільнення і реабілітації з них дожили одиниці. }\end{array}$ \\
\hline $1930-1937$ & $\begin{array}{l}\text { Ліквідовано українські школи, середні спеціальні та вищі навчальні заклади } \\
\text { та факультети, закрито газети й видавництва поза межами України - на } \\
\text { Кубані, у Сибіру, на Далекому Сході та інших землях, заселених переважно } \\
\text { українцями. «Постановление ЦК ВКП(б) и СНК Союза ССР о } \\
\text { хлебозаготовках на Украине, Северном Кавказе и Западной области от } 14 \\
\text { декабря } 1932 \text { г.: «7... д) немедленно перевести на Северном Кавказе } \\
\text { делопроизводство советских и кооперативных органов «украинизированных» } \\
\text { районов, а также все издающиеся газеты и журналы с украинского языка на } \\
\text { русский как более понятный для кубанцев, а также подготовить и к осени } \\
\text { перевести преподавание в школах на русский язык.., срочно проверить и } \\
\text { улучшить состав работников школ в «украинизированных» районах». }\end{array}$ \\
\hline $1932-1933$ & $\begin{array}{l}\text { Сплановано і здійснено за мовчазною згодою «світового співтовариства» } \\
\text { акцію ліквідації українського народу. Свідоме знищення більшовицьким } \\
\text { режимом українських селян організацією голодомору. Централізоване } \\
\text { переселення росіян у вимерлі села України. В Україні, яка володіє } 40 \text { \% } \\
\text { світового чорнозему, померло від голоду } 10-12 \text { мільйонів носіїв } \\
\text { української мови. }\end{array}$ \\
\hline 1933 & $\begin{array}{l}\text { Скасування в Румунії міністерського розпорядження від } 31 \text { грудня } 1929 \text { р., } \\
\text { яким дозволялося кілька годин української мови на тиждень у школах і3 } \\
\text { більшістю учнів-українців. Телеграма Сталіна про припинення українізації } \\
\text { і знищення більшості українських письменників. } 3 \text { українського правопису } \\
\text { вилучено літеру «Г». }\end{array}$ \\
\hline $1933-1941$ & $\begin{array}{l}\text { Тотальне знищення та арешт 80\% української інтелігенції російською } \\
\text { окупаційною владою: інженерів, науковців, письменників, лікарів, } \\
\text { учителів тощо. До } 1938 \text { р. друкувалося } 259 \text { українських письменників, } \\
\text { після } 1938 \text { р. - лише } 36 \text {. Із } 223 \text { зниклих письменників лише семеро } \\
\text { померли своєю смертю. Решту розстріляно, запроторено до концтаборів, } \\
\text { іншими репресивними заходами вилучено з літератури. }\end{array}$ \\
\hline 1934 & $\begin{array}{l}\text { Спеціальне розпорядження Міністерства виховання Румунії про } \\
\text { звільнення } 3 \text { роботи «за вороже ставлення до держави і румунського } \\
\text { народу» всіх українських учителів, які вимагали повернення до школи } \\
\text { української мови. }\end{array}$ \\
\hline
\end{tabular}




\begin{tabular}{|c|c|}
\hline $\begin{array}{l}\text { 30-ті } \\
\text { роки } \\
\text { далі }\end{array}$ & 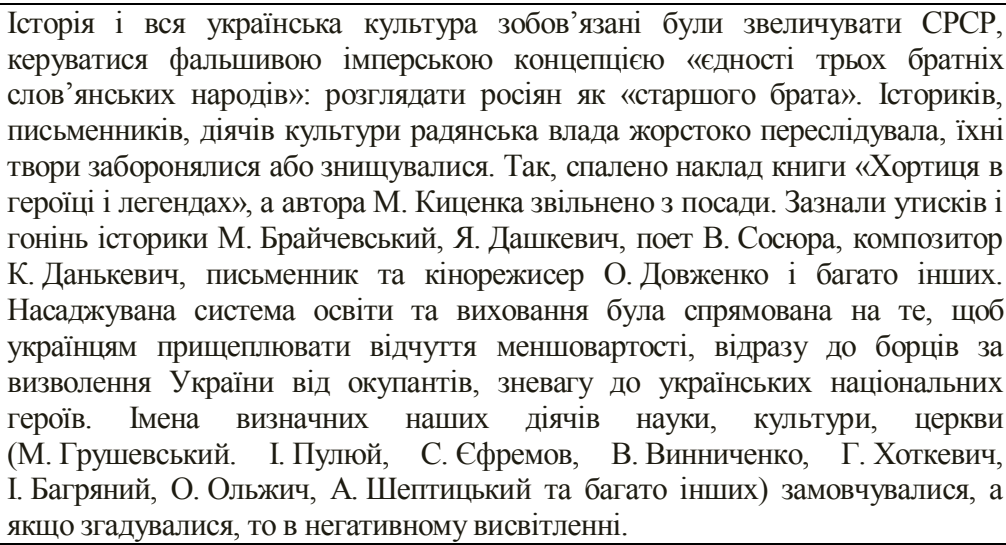 \\
\hline 1937 & $\begin{array}{l}\text { На відзначення 20-річчя приходу комуністів до влади на Соловках } \\
\text { розстріляно понад тисячу діячів української культури. }\end{array}$ \\
\hline 1938 & $\begin{array}{l}\text { Постанова РНК СРСР і ЦК ВКП(б) «Про обов’язкове вивчення російської } \\
\text { мови в школах національних республік і областей», відповідна постанова } \\
\text { РНК УРСР і ЦК КП(б)У. }\end{array}$ \\
\hline 1939 & $\begin{array}{l}\text { Перепис населення Кубані показав, що внаслідок голодомору, арештів і } \\
\text { примусового виселення кількість українців там із 61,5\% у } 1926 \text { р. } \\
\text { зменшилася до } 4 \text { \%. Після «визволення» Західної України - закриття } \\
\text { багатьох українських і відкриття російських шкіл. }\end{array}$ \\
\hline 1940 & Депортація населення Галичини в Сибір. \\
\hline 1946 & $\begin{array}{l}\text { Постанова Ради Міністрів СРСР «Про затвердження українського правопису, } \\
\text { наближеного до російського». Постанова ЦК ВКП(б) про «український } \\
\text { буржуазний націоналізм», унаслідок якої кілька тисяч представників } \\
\text { української інтелігенції заслано до концтаборів («Ждановщина»). Гоніння на } \\
\text { журнали «Україна», «Радянський Львів», «Дніпро», «Барвінок», «Перець». }\end{array}$ \\
\hline 1947 & $\begin{array}{l}\text { У Польщі операція «Вісла»: розселення частини українців з етнічних } \\
\text { українських земель «урозсип» між поляками в західних районах країни } \\
\text { задля прискорення їхньої полонізації. Депортація в Сибір населення } \\
\text { Західної України. Вивезення загалу українців до Сибіру не було } \\
\text { здійснено тільки через нестачу вагонів. «Чистка» серед діячів української } \\
\text { культури з обвинуваченням їх у націоналізмі новопризначеним із Москви } \\
\text { секретарем ЦК КП(б)У Л. Кагановичем. Видано таємну інструкцію (на } \\
157 \text { сторінках) про вилучення } 3 \text { книгозбірень і списання в макулатуру } \\
3600 \text { назв книжок, автори яких були названі українськими буржуазними } \\
\text { націоналістами, ворогами народу. П’ятий параграф інструкції застерігав: } \\
\text { «Особи, що загублять цей зведений список, підлягають притягненню до } \\
\text { судової відповідальності». }\end{array}$ \\
\hline 1949 & $\begin{array}{l}\text { XVI з’їзд КП(б)У вкотре засуджує український буржуазний націоналізм, } \\
\text { погрожує українським діячам науки й культури, які ще залишилися на } \\
\text { волі, вимагає від них таврувати «Гнилу культуру буржуазного Заходу»й } \\
\text { вихваляти «передову культуру» СРСР. Заборона повертатися в Україну }\end{array}$ \\
\hline
\end{tabular}

(c) Н. М. Малюга, 2014. 


\begin{tabular}{|c|c|}
\hline & $\begin{array}{l}\text { тим робітникам, які були вивезені під час війни разом зі своїми заводами. } \\
\text { Для відбудови промисловості в Україні присилали росіян. На цілину - у } \\
\text { Казахстан та Сибір - вивезено } 100 \text { тисяч українських юнаків та дівчат. }\end{array}$ \\
\hline 1951 & $\begin{array}{l}\text { Викриття газетою «Правда» - центральним органом ЦК ВКП(б) - } \\
\text { «націоналістичних ухилів» в українській літературі (вірш В. Сосюри } \\
\text { «Любіть Україну», лібрето опери «Богдан Хмельницький» і т. ін.). } \\
\text { Студенти Харківського університету відмовилися складати іспити } \\
\text { російською мовою. Тоді } 8003 \text { них репресовано, а } 33 \text { студентів на } \\
\text { закритому засіданні суду засуджено до смертної кари і розстріляно. }\end{array}$ \\
\hline 1958 & $\begin{array}{l}24 \text { грудня } 1958 \text { р. Верховна Рада СРСР ухвалила закон, згідно з яким питання } \\
\text { про те, вивчати чи не вивчати рідну мову в національних школах мають } \\
\text { вирішувати батьки та самі учні (ст. } 20 \text { Основ Законодавства СРСР і союзних } \\
\text { республік про народну освіту). Останніх наполегливо спонукали розв’ язувати } \\
\text { це питання } 3 \text { погляду так званої практичної доцільності (мовляв, для чого } \\
\text { «перевантажувати» себе). Постанова Пленуму ЦК КПРС про перехід частини } \\
\text { українських шкіл на російську мову викладання. } 17 \text { вересня } 1959 \text { р. Верховна } \\
\text { Рада УРСР прийняла відповідну Постанову. }\end{array}$ \\
\hline $1960-1980$ & Масове закриття українських шкіл у Польщі та Румунії. \\
\hline 1961 & $\begin{array}{l}\text { ХХІІ з’їзд ЦК КПРС проголосив політику «злиття націй», що, по суті, } \\
\text { означало тотальне зросійщення народів СРСР. («Слід з усією більшовицькою } \\
\text { непримиренністю викорінювати навіть найменші прояви націоналістичних } \\
\text { пережитків», тобто звичаї, мову, культуру поневолених народів). }\end{array}$ \\
\hline 1962 & $\begin{array}{l}\text { Репресії проти захисників української мови. ЦК компартії України } \\
\text { зобов’язує комуністів та місцеву адміністрацію «рішуче виступати проти } \\
\text { консервативних традицій і звичаїв, проти будь-яких пережитків } \\
\text { буржуазного націоналізму», найшкідливішими з яких, на думку влади, } \\
\text { було знання рідної мови, потяг до вивчення своєї історії та культури. }\end{array}$ \\
\hline 1964 & $\begin{array}{l}\text { Агент КДБ пересипає фосфором і спалює частину приміщення Центральної } \\
\text { наукової бібліотеки в Києві. На прилеглій території заздалегідь відключили } \\
\text { воду, а пожежники приїхали лише через } 4 \text { години після підпалу. Вогонь } \\
\text { знищив понад } 600 \text { тис. томів цінних українських архівних документів. }\end{array}$ \\
\hline 1965 & $\begin{array}{l}\text { Хвиля політичних процесів проти «українських інакодумців» } \\
\text { (Б. та М. Горині, О. Заливаха, В. Мороз, М. Осадчий, А. Шевчук та ін.). }\end{array}$ \\
\hline $1969-1979$ & $\begin{array}{l}\text { Серія загадкових пожеж у відділах україністики в бібліотеках Академії } \\
\text { наук, музею «Софія Київська», у книгосховищі Видубицького монастиря } \\
\text { в Києві, медичного інституту в Тернополі, Успенської церкви та Музею } \\
\text { українського мистецтва у Львові. }\end{array}$ \\
\hline 1970 & $\begin{array}{l}\text { Суд над авторами «Листа творчої молоді Дніпропетровська» } 3 \text { протестом } \\
\text { проти російщення української культури. Наказ Міністерства освіти СРСР } \\
\text { про написання і захист дисертацій лише російською мовою; російською } \\
\text { мовою мусили виконуватися та захищатися навіть дисертації } 3 \text { питань } \\
\text { української мови та літератури. }\end{array}$ \\
\hline 1972 & $\begin{array}{l}\text { Заборона партійними органами відзначати ювілей музею І. Котляревського в } \\
\text { Полтаві. «За недостатню боротьбу з націоналістичними проявами» усунуто від } \\
\text { партійного керівництва першого секретаря ЦК КПУ П. Шелеста (критика } \\
\text { партійними цензорами його книжки під назвою «Україна наша радянська», у }\end{array}$ \\
\hline
\end{tabular}




\begin{tabular}{|c|c|}
\hline & $\begin{array}{l}\text { якій прославлялося запорозьке козацтво), звільнено з Вищої партійної школи } \\
\text { при ЦК КПУ } 34 \text { викладачі разом із директором, заборонено книги майже сотні } \\
\text { авторів, звільнено чверть секретарів з ідеологічних питань на всіх партійних } \\
\text { рівнях, піддано чищенню низку наукових установ, а також Київський та } \\
\text { Львівський університети. У Харкові знесено хату, де жив видатний } \\
\text { український філософ і просвітник Г. Сковорода, та розпочато знищення } \\
\text { цвинтаря, де поховано багато визначних діячів української науки й культури. }\end{array}$ \\
\hline $1972-1974$ & $\begin{array}{l}\text { Політичні репресивні процеси проти українських дисидентів. Загалом } \\
\text { заарештовано за два роки кілька тисяч осіб. Заарештовані, яких не } \\
\text { засудили, звільнені з роботи або понижені в посадах. У ці роки були } \\
\text { засуджені: Є. Сверстюк, І. Світличний, І. Дзюба, В. Стус, Ігор та Ірина } \\
\text { Калинці, Н. Світлична, В. Чорновіл, С. Шабатура, О. Мешко, О. Попович, } \\
\text { І. Кандиба, Л. Лук’яненко, В. Романюк, І. Гель, повторно Ю. Шухевич. }\end{array}$ \\
\hline 1973 & Заборона відзначати ювілей твору I. Котляревського «Енеїда». \\
\hline 1975 & Нова цензура «Кобзаря» Тараса Шевченка. \\
\hline 1978 & $\begin{array}{l}\text { Постанова ЦК КПРС і Ради Міністрів СРСР «Про заходи щодо } \\
\text { подальшого вдосконалення вивчення і викладання російської мови в } \\
\text { союзних республіках» (т. зв. «Брежнєвський циркуляр»). На Чернечій } \\
\text { (Тарасовій) горі у Каневі спалив себе Олекса Гірник (з Калуша) на знак } \\
\text { протесту проти русифікації України. }\end{array}$ \\
\hline 1979 & $\begin{array}{l}\text { Ташкентська конференція «Російська мова - мова дружби і співпраці народів } \\
\text { СРСР» накреслила нові заходи щодо російщення неросійських народів. } \\
\text { Зокрема «рекомендувалося» ширше впроваджувати російську мову в } \\
\text { дошкільні заклади (як наслідок- українські дитячі садки практично зникли), } \\
\text { російською мовою провадити позакласну й позашкільну роботу, «сприяти» } \\
\text { тому, щоб студенти писали російською свої реферати, доповіді, курсові та } \\
\text { дипломні праці, а також звіти про виробничу й педагогічну практику. Так } \\
\text { само «рекомендувалося», щоб у тих ВНЗ, де національна мова ще якось } \\
\text { функціонувала (наприклад, у Західній Україні), російською, починаючи з 2- } \\
\text { 3-х курсів, читали суспільні, загальноосвітні та спеціальні дисципліни. } \\
\text { Показово, що для контролю виконання цієї «рекомендації» Міністерство } \\
\text { вищої та середньої спеціальної освіти УРСР запровадило навіть спеціальну } \\
\text { форму звітності, що зобов’язувала ректорів регулярно подавати Міністерству } \\
\text { «перелік спеціальних дисциплін, які викладаються російською мовою» на } \\
\text { кожному з факультетів керованого ними навчального закладу. }\end{array}$ \\
\hline 1983 & $\begin{array}{l}\text { Постанова ЦК КПРС і Ради Міністрів СРСР «Про додаткові заходи } 3 \\
\text { поліпшення вивчення російської мови в загальноосвітніх школах та } \\
\text { інших навчальних закладах союзних республік» (так званий } \\
\text { «Андроповський указ»). }\end{array}$ \\
\hline 1984 & $\begin{array}{l}\text { Наказ Міністерства культури СРСР про переведення діловодства в усіх } \\
\text { музеях Радянського Союзу на російську мову. Початок в УРСР виплат } \\
\text { підвищеної на } 15 \text { \% зарплатні вчителям російської мови. }\end{array}$ \\
\hline 1984-1985 & $\begin{array}{l}\text { У концтаборах замордовано Юрія Литвина, Валерія Марченка, Василя } \\
\text { Стуса, Олексу Тихого. }\end{array}$ \\
\hline 1989 & $\begin{array}{l}\text { Постанова ЦК КПРС про «законодавче закріплення російської мови як } \\
\text { загальнодержавної». Те ж у проекті Конституції М. Горбачова. }\end{array}$ \\
\hline
\end{tabular}

(c) Н. М. Малюга, 2014. 


\begin{tabular}{|c|c|}
\hline 1990 & $\begin{array}{l}\text { Верховна Рада Радянського Союзу ухвалює Закон про мови народів } \\
\text { Радянського Союзу, який закріплює за російською статус офіційної на } \\
\text { всій території СРСР. }\end{array}$ \\
\hline $1993-1995$ & $\begin{array}{l}\text { Посилення антиукраїнського терору в освіті, культурі, засобах інформації. } \\
\text { Убито кілька десятків активістів національних українських партій та } \\
\text { організацій у різних містах України, зокрема голову секретаріату Руху } \\
\text { Михайла Бойчишина, спалено хату-музей Тараса Шевченка. Жодного } \\
\text { злочинця з цих справ не засуджено і навіть не заарештовано. }\end{array}$ \\
\hline 1994 & $\begin{array}{l}\text { Намагання надати російській мові статус офіційної в незалежній, вільній, } \\
\text { суверенній, самостійній Україні. Заява Президента України Л. Кучми про } \\
\text { його намір внести поправки до чинного законодавства задля надання } \\
\text { російській мові статусу державної. Як наслідок - призупинення } \\
\text { відновлення українських шкіл, переведення частини українських класів і } \\
\text { шкіл на російську мову навчання. }\end{array}$ \\
\hline 1995 & $\begin{array}{l}\text { Міністерство національностей України розробило напівтаємний «Проект } \\
\text { державної програми... розвитку російської культури в Україні до } 2000 \text { року», } \\
\text { у якому одна } 3 \text { «національних меншин» отримувала більші права, ніж } \\
\text { українці. У Харкові відкрито пам’ятник україножеру маршалові Г. Жукову, } \\
\text { який у кінці війни підписав наказ про виселення з України всіх українців. }\end{array}$ \\
\hline $\begin{array}{l}1998- \\
\text { поч. ХХІ ст. }\end{array}$ & $\begin{array}{l}\text { У зв’язку з інформаційною революцією 90-х років російщення України } \\
\text { відбувається ще більш інтенсивно. Інформаційний простір України майже } \\
\text { повністю зрусифіковано. Неукраїнська, а часом антиукраїнська політика } \\
\text { урядів України призвела до того, що державну мову з української преси } \\
\text { витіснила мова сусідньої країни, співвідношення між українськомовною } \\
\text { та російськомовною пресою - 1:10. }\end{array}$ \\
\hline
\end{tabular}

Далі за наведеним зразком учитель разом з учнями може укласти таблицю фіксації подій останнього десятиліття, спрямованих на нищення української мови і культури.

Ефективна методика викладання української мови може створюватися й удосконалюватися лише за умови постійного й усебічного врахування досягнень науки про мову. Шкільна програма 3 української мови містить вступні теми, які вимагають від учителя глибокої теоретичної підготовки. Серйозні теоретичні знання про мову потрібні вчителю не лише для кваліфікованого викладу складних дражливих тем (зокрема, періодизації історії української мови, обмеження функціонування рідної мови етносу), але й для успішного вирішення нагальних завдань навчання української мови відповідно до вимог чинної програми, яка передбачає ознайомлення учнів зі значним обсягом теоретичних відомостей.

\section{Література}

1. Малюга Н. М. Мовознавство : упровадження результатів пізнання в практику сучасної школи / Н. М. Малюга // Вересень. - 2005. - №1-2. - С. 14-19. 
2. Малюга Н. М. Уроки загальнолінгвістичної тематики в 6-7 класах : посилення інформаційної складової / Н. М. Малюга // Філологічні студії : Науковий вісник Криворізького державного педагогічного університету : зб. наук. праць. - Кривий Ріг : Видавничий дім, 2008. - Вип. 2.- С.113-120.

3. Малюга Н.М. Мовознавство в питаннях і відповідях для вчителя й учнів 5 класу / Н. М. Малюга // Філологічні студії : Науковий вісник Криворізького державного педагогічного університету : зб. наук. праць .- Кривий Ріг : Видавничий дім, 2008. Вип.1. - С.142-150.

4. Українська мова 5-12 класи : Програма для загальноосвітніх навчальних закладів : навчально-практичне видання. - К. : Вид-во ВТФ «Перун», 2005. - 176 с.

Стаття надійшла до редакиії 07.11.2014 p. 